\title{
PERAN PEMBIAYAAN MUDHARABAH DALAM PENGEMBANGAN KINERJA USAHA MIKRO PADA BMT (BAITUL MAAL WAT TAMWIL)
}

\author{
Ernanda Kusuma Dewi dan Ayu Astari \\ Fakultas Ekonomi Jurusan Manajemen \\ Universitas Islam Sultan Agung Semarang \\ ernandakusuma@std.unissula.ac.id \\ ayuastari95@gmail.com
}

\begin{abstract}
Abstrak

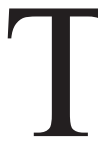
ulisan ini merupakan artikel konseptual untuk mengetahui peran pembiayaan mudharabah pada BMT (Baitul Maal wat Tamwil) dalam pengembangan kinerja usaha mikro. Pengembangan kinerja usaha mikro dapat berkembang dengan beberapa faktor seperti pembinaan dan pengawasan. Pembiayaan mudharabah merupakan pembiayaan yang sangat sesuai dengan usaha mikro. Sehingga diharapkan pembiayaan mudharabah mempunyai peran dalam pengembangan kinerja usaha mikro. Artikel ini dituliskan berdasarkan kajian pustaka dari literature dan penelitian sebelumnya dibidang pembiayaan syariah untuk membangun model. Terdapat beberapa faktor yang mendorong suksesnya pembiayaan mudharabah di BMT dalam pengembangan kinerja usaha mikro.
\end{abstract}

Kata Kunci: Pembiayaan Mudharabah, Kinerja Usaha Mikro, BMT

\begin{abstract}
$T$ Ihis paper is a conceptual article to find out the role of financing in the BMT (Baitul Maal wat Tamwil) in the development of micro-enterprises performance. Development of micro-enterprises can flourish performance to several factors such as guidance and supervision. Financing is a very appropriate financing to micro-enterprises. So expect of financing has a role in the development of micro-enterprises performance. This article is written based on literature review of the literature and previous research in the field of Islamic finance to build the model. There are several factors that drive the success of financing in the BMT in developing the performance of micro-enterprises
\end{abstract}

Keywords: Mudharabah financing, Performance Micro Enterprises, BMT

\section{PENDAHULUAN}

Lembaga keuangan Islam saat ini bukan merupakan hal yang asing lagi di dunia, baik Negara Islam maupun Negara non-Islam. Di Indonesia, lembaga keuangan Islam saat ini mengalami perkembangan yang cukup pesat. Hal ini ditandai dengan semakin banyaknya lembaga-lembaga keuangan Islam yang berdiri di Indonesia dibandingkan denganbeberapa tahun yang lalu. Terbukti sejak tahun 1991 sampai dengan 2016, telah banyak berdiri berbagai lembaga keuangan Islam salah satunya Bank Muamalat Indonesia yang merupakan Bank Islam pertama di Indonesia yang sampai saat ini berbagai bank Islam telah muncul. Selain itu juga telah muncul lembaga keuangan Islam lainnya seperti Asuransi Islam, Pengadaian Islam, dan lembaga keuangan mikro Islam.

Lembaga keuangan mikro Islam juga mengalami perkembangan yang sangat berarti. Lembaga keuangan mikro Islam mempunyai peran sebagai wadah penyaluran maupun permodalan dana bagi masyarakat kalangan menengah kebawah sehingga mampu menjadi salah satu unsur dalam 
perkembangan perekonomian di Indonesia. Lembaga-lembaga yang merupakan lembaga keuangan mikro Islam yaitu Koperasi Syariah, dan Baitul Maal wat Tamwil (BMT).

BMT merupakan lembaga keuangan mikro yang menggunakan prinsip syariah dan berlandaskan ajaran Islam. Secara etimologis Baitul Maal wat Tamwil terdiri dari dua arti yakni Baitul Maal yang berarti "rumah uang" dan Baitul Tamwil dengan pengertian "rumah pembiayaan". I Gde Kajeng (2013) ${ }^{1}$ menjelaskan rumah uang dalam artian ini adalah pengumpulan dana yangberasal dari zakat, infaq, ataupun shodaqah, dan pembiayaan yang dilakukan adalah berdasarkan prinsip bagi hasil, yang berbeda dengan sistem perbankan konvensional yang mendasarkan pada sistem bunga. Bunga merupakan riba yang dibenci Allah SWT.

Firman Allah SWT QS. al-Baqarah [2]: 275²

"Dan Aku halalkan bagimu jual beli, dan Aku haramkan bagimu riba...".

Berdasarkan data yang dilansir dari Republika.co.id $(22 / 3 / 2015)^{3}$ menyatakan bahwa asset BMT hingga tahun 2015 mencapai 4,6 Triliun rupiah. Dengan pembiayaan sekitar 3,6 Triliun rupiah. Pendirian BMT didasarkan pada tujuan penggiatan kualitas usaha dalam bidang perekonomian yaitu, meningkatkan kegiatan usaha mikro disekitar BMT tersebut. BMT merupakan lembaga yang bergerak dalam pengembangan sector riilyang mempunyai tujuan harapan masyarakat sebagai pusat uni kegiatan khusunya kegiatan usaha mikro. BMT sebagai lembaga keuangan mikro Islam diharapkan mampu menjadi jantung bagi kegiatan ekonomi masyarakat lapisan bawah. Kegiatan keuangan di BMT yang jauh dari riba mampu bertahan dalam kondisi apapun seperti krisis moneter dan naiknya suku bunga sebab sistem yang digunakan mengacu pada bagi hasil bukan dengan sistem bunga. Dalam Islam sistem bagi hasil yaitu pembiayaan musyarakah dan pembiayaan mudharabah.

Pembiayaan mudharabah mengalami penurunan pada bulan Maret tahun 2008-2016. Tahun 2008 prosentase pembiayaan mudharabah sebesar 16,25\% dan setiap tahunnya mengalami penurunan hingga tahun 2016 prosentasenya hanya sebesar 6,60\% (Statistik Perbankan Syariah, Bank Indonesia, Mei 2016, data diolah kembali) ${ }^{4}$. Walaupun nilai dari pembiayaan mudhrabah meningkat setiap tahunnya tetap saja porsi pembiayaan mudharabah menurun dibanding pembiayaan lainnya seperti pembiayaan musyarakah, pembiayaan murabahah dan lainnya. Porsi pembiayaan tertinggi diraih oleh pembiayaan murabahah, dari tahun 2008 prosentasenya sebesar $58,87 \%$ dan tahun 2016 sebesar 56,50\%, nilai yang sangat jauh dengan pembiayaan mudharabah. Dari fakta ini dapat dilihat bahwa pihak perbankan syariah masih sangat memperhatikan aspek kehati-hatian dalam pembiayaan mudharabah sehingga hasil yang diperoleh masih belum maksimal. Padahal sebenarnya pembiayaan murabahah merupakan produk pembiayaan sekunder setelah pembiayaan primer yaitu pembiayaan mudharabah dan pembiayaan musyarakah. Dominannya pembiayaan murabahah membuat eksistensi pembiayaan mudharabah semakin hilang, padahal pembiayaan yang paling ideal bagi kegiatan usaha mikro yaitu pembiayaan mudharabah. Masalah ini juga terjadi di BMT, rendahnya pembiayaan mudharabah diiringi dengan kurangnya pengetahuan terhadap pembiayaan ini sendiri. Beda dengan pembiayaan murabahah yang secara konsep lebih cepat dimengerti.

Menurut Fatwa DSN MUI tahun 2000 pembiayaan mudharabah adalah pembiayaan yang disalurkan oleh lembaga keuangan Islam kepada pihak lain untuk suatu usaha yang produktif. Pembiayaan mudharabah merupakan akad kerja sama antara kedua pihak dimana pihak pertama menyediakan seluruh modal (shahibul maal) dan pihak kedua sebagai pengelola dana (mudharib), sedangkan keuntungan usaha dengan bagi hasil yang sesuai kesepakatan kontrak. Nisbah

1 Bagaskara, I. G. K. Lembaga Keuangan Mikro di Indonesia. Jurnal Buletin Studi Ekonomi, Vol.18(2), 114-125, 2013

2 Al-Quran dan Terjemahan, Al-Quran Tajwid dan Terjemah, Bandung:Diponegoro, 2010

3 Republika. Aset BMT Indonesia Capai Rp 4,7 Triliun. Retrieved from http://www.republika.co.id/berita/ekonomi/ syariah-ekonomi/15/03/22/nlmhlb-aset-bmt-indonesia-capai-rp-47-triliun, 2015

4 Bank Indonesia: Statistik Perbankan Syariah. Retrieved from http://www.bi.go.id/id/statistik/perbankan/ syariah/Default.aspx, 2016. 
keuntungan pada pembiayaan mudharabah adalah imbalan untuk kedua pihak yaitu pemberi modal dan pelaku usaha. Pembiayaan mudharabah mempunyai beberapa kelebihan serta keuntungan yang lebih untuk usaha mikro seperti dalam hal bagi hasil. Pelaku usaha mikro dapat membayar angsuran melalui keuntungan bersih yang didapat setelah melakukan usaha sehingga adil baik bagi shahibul maal dan mudharib. Pembiayaan mudharabah juga meringankan angsuran karena jika suatu usaha belum mempunyai keuntungan maka shahibul maal dapat dengan sabar menunggu sampai mudharib mampu membayar angsurannya. Pembiayaan mudharabah adalah pembiayaan yang ideal khususnya bagi para pelaku kegiatan usaha mikro.

Usaha mikro memiliki peran yang strategis di dalam menciptakan peluang kerja dan membantu perekonomian negara. Saat krisis ekonomi yang terjadi di Indonesia banyak perusahaan besar yang bangkrut karena dilanda hutang, tapi saat masa krisis tersebut usaha mikro dapat bertahan dari kebangkrutan, hal itu disebabkan karena modal yang digunakan usaha mikro sangat kecil. Permodalan usaha mikro melalui BMT dinilai sangat tepat karena BMT menggunakan sistem bagi hasil yang tidak memberatkan pelaku usaha.

Dengan demikian bahwa peran BMT sebagai lembaga keuangan mikro Islam yang menangani sektor lapisan bawah harus melakukan peningkatan kualitas secara terus menerus. Pengenalan sistem ekonomi Islam perlu dilakukan agar masyarakat tidak terjebak dalam arus riba. BMT harus melakukan penanganan yang serius dalam upaya meningkatkan pembiayaan yang ideal yaitu pembiayaan mudharabah untuk menjadi pembiayaan bagi pelaku usaha mikro. Citra pembiayaan mudharabah harus dapat direbut kembali agar sistem ekonomi Islam mampu berjalan dengan baik. Semakin banyak usaha mikro maka secara langsung akan membantu pertumbuhan perekonomian di Indonesia. Umat muslim akan lebih mandiri dalam perekonomian hidupnya. Serta akan mensejahterakan kehidupan masyarakat indonesia karena lapangan pekerjaan semakin banyak dan bertambah sangat luas.

Penelitian Widiyanto $(2007)^{5}$ tentang efektivitas dan keberlanjutan pembiayaan pada BMT dalam pengembangan usaha mikro memberikan saran untuk meniliti lebih lanjut bagaimana pengaruh pembiayaan Islam secara detail bagi keberlanjutan usaha mikro. Dalam penelitian tersebut dijelaskan bahwa pengaruh seluruh jenis produk pembiayaan (mudharabah, musyarakah, murabahah, ijarah, dan qard hasan) secara umum memiliki dampak yang positif bagi usaha mikro.

Uraian diatas menjelaskan bahwa pembiayaan mudharabah harus dapat dipertahankan untuk membantu masyarakat lebih mandiri melalui usaha mikro. Pembiayaan mudharabah merupakan pembiayaan primer dalam produk pembiayaan Islam yang sudah diakui banyak ulama dan pihak-pihak yang paham mengenai ekonomi maupun keuangan Islam. Diharapkan pembiayaan mudharabah dapat meningkat dari tahun ke tahun dan peminatnya bertambah serta penerapan pembiayaan mudharabah pada lembaga keuangan Islam khusunya BMT yang merupakan lembaga keuangan mikro Islam dapat lebih sesuai dengan prinsip syariah melalui DSN MUI agar pelaku usaha mikro lebih bertambah. Sehingga penelitian ini bertujuan untuk mengetahui peran pembiayaan mudharabah dalam pengembangan usaha mikro dan praktiknya apakah sesuai dengan standar DSN MUI.

\section{HASIL DAN PEMBAHASAN}

\section{Kinerja Usaha Mikro}

Krisis ekonomi yang memporak-porandakan perekonomian Indonesia tahun 1997 yang lalu membangkitkan kesadaran pentingnya peran Usaha Kecil dan Menengah (UKM) sebagai tulang punggung perekonomian Indonesia. UMKM dapat di definisikan secara terpisah baik dari usaha mikro, usaha kecil, dan usaha menengah. Menurut Kementrian Menteri Negara Koperasi dan Usaha Kecil Menengah (Menegkop dan UKM) tahun 2008, bahwa yang dimaksud dengan Usaha Kecil(UK), termasuk Usaha Mikro (UMI), adalah entitas usaha yang

$5 \quad$ Widiyanto. Effectiveness and Sustainability of Baitul Mal Wat Tamwil Financing In The Development of Microenterprises In Central Java, Indonesia. Phd Thesis, UPM Malaysia, 2007. 
mempunyai memiliki kekayaan bersih paling banyak Rp 200.000.000, tidak termasuk tanah dan bangunan tempat usaha, dan memilikipenjualan tahunan paling banyak Rp 1.000.000.000. Usaha mikro dinilai lebih aktif dalam memberi pengaruh bagi perekonomian di Indonesia. Data BPS menunjukan pada tahun 2010 jumlah usaha mikro sebanyak 2.529 .847 dan jumlah ini mengalami peningkatan pada tahun 2015 sebesar sebanyak 3.385.851. Di Jawa Tengah sendiri jumlah usaha mikro pada tahun 2015 sebanyak 934.814. Hal ini membuktikan bahwa minat usaha mikro di Jawa Tengah paling banyak dibandingkan dengan provinsi lain di Indonesia. (BPS, Agustus 2016) ${ }^{6}$. Banyaknya jumlah usaha mikro di Jawa Tengah mempunyai potensi yang besar bagi perkembangan perekonomian.

Menurut UU No.20 tahun 2008 tentang Usaha Mikro, Kecil, dan Menengah disebutkan bahwa Usaha mikro adalah usaha produktif milik orang perorangan dan/atau badan usaha perorangan yang memenuhi kriteria usaha mikro sebagaimana diatur dalam undang-undang ini. Adapun kriteria usaha mikro pada Pasal 6 ayat (1), disebutkan bahwa :

a. Usaha mikro memiliki kekayaan yang bersih paling banyak Rp 50.00.000,00 (lima puluh juta rupiah) tidak termasuk tanah dang bangunan tempat usaha: atau

b. Memiliki hasil penjualan tahunan paling banyak Rp 300.000.000,00 (tiga ratus juta rupiah).

Usaha mikro(SK. Direktur BI No.31/24//Kep/DER tanggal 5 Mei 1998) adalah usaha yang dijalankan oleh rakyat miskin atau mendekati miskin. Dimiliki oleh keluarga sumber daya lokal dan teknologi sederhana. Lapangan usaha mudah untuk exit dan entry.

Dewi (2016) ${ }^{7}$ menjelaskan bahwa kriteria untuk usaha mikro yaitu: memiliki aset dibawah UMR (Upah Minimum Rata-rata), usaha telah berjalan kurang lebih 1 tahun, nasabah atau mitra merupakan satu-satunya anggota keluarga yang bekerja artinya nasabah sebagai tulang punggung keluarga, serta tidak memungkinkan untuk melakukan linked ke perbankan.

Usaha mikro merupakan usaha produktif yang memilki sumber daya maupun teknologi sederhana serta memiliki kekayaan bersih dibawah Rp 50.000.000,00. Sehingga usaha mikro dapat dibantu dalam hal permodalan oleh BMT yang sangat dekat dengan masyarakat menengah kebawah.

Ciri-ciri usaha Mikro menurut Indriyatni $(2013)^{8}$ adalah :

a. Jenis komoditi usahanya tidak selalu tetap, sewaktu-waktu dapat berganti.

b. Tempat usahanya tidak selalu menetap, sewaktu-waktu dapat berpindahtempat.

c. Belum melakukan administrasi keuangan yang sederhana sekalipun, dantidak memisahkan keuangan keluarga dengan keuangan usaha.

d. Tingkat pendidikan yang rata-rata masih rendah.

e. Umumnya tidak memiliki ijin usaha atau persyaratan legalitas lainnya, seperti NPWP.

f. Umumnya belum memiliki akses kepada perbankan, tapi sebagian dari mereka sudah akses ke lembaga keuangan non Bank seperti lembaga keuangan mikro.

Semuel (2014) $)^{9}$ menjelaskan kinerja adalah hasil kerja yang dapat dicapai seseorang atau sekelompok orang dalam suatu perusahaan atau bada usaha sesuai dengan tanggung jawab masing-masing dalam upaya pencapaian tujuan perusahaan secara legal, tidak melanggar hukum, tidak bertentangan dengan etika dan dipengaruhi oleh kemampuan, keinginan,

6 Badan Pusat Statitistik: Industri Mikro dan Kecil. Retrieved from https://www.bps.go.id/Subjek/view/ id/170\#subjekViewTab3|accordion-daftar-subjek2, 2016.

7 Dewi, A. P. Pembiayaan Bagi Hasil Sektor Usaha Mikro di BMT Hasanah Ponorogo. Muslim Heritage, Vol.1(1), 73-85, 2016.

8 Indriyatni, L. Analisis Faktor-Faktor yang Berpengaruh Terhadap Keberhasilan Usaha Mikro dan Kecil ( Studi pada Usaha Kecil di Semarang Barat ). Jurnal STIE Semarang, Vol.5(1), 54-70, 2013.

9 Semuel, H. Penerapan Kebijakan Penggunaan Energi Listrik Terhadap Kinerja Usaha Mikro Kecil dan Menengah di Provinsi Jawa Timur. Jurnal Manajemen Pemasaran, Vol.8(1), 3-46, 2014. 
lingkungan, dan kesempatan yang tercermin sebagai budaya kualitas kerja organisasi secara keseluruhan. Kinerja suatu perusahaan atau badan usaha dapat dimaknai sebagai pencapaian maksimal dari tujuan badan usaha yang ditandai oleh efisiensi secara menyeluruh dalam proses pencapaian tujuan. Sehingga kinerja usaha mikro yaitu proses pencapaian tujuan yang dilakukan dalam berbagai aspek baik aspek keuangan, sumber daya manusia, teknologi serta produksi untuk dapat mencapai tujuan usaha mikro. Peningkatan dari keuntungan usaha serta kesejahteraan para pelaku usaha mikro yang terlibat serta kemandirian masyarakat yang dicapai merupakan tujuan dari usaha mikro

\section{Pengembangan Usaha Mikro}

Seperti yang disebutkan bahwa usaha mikro sangat memiliki potensi yang besat terhadap perkembangan perekonomian di Indonesia sehingga perlu diadakan pengembang usaha mikro itu sendiri. Dalam Kamus Besar Bahasa Indonesia, pengembangan adalah sebuah proses, cara dan perbuatan mengembangkan. Pengembangan usaha mikro dapat dilakukan karena usaha mikro memiliki potensi yang besar.Pengembangan usaha mikro diupayakan agar dapat menjangkau perekenomian di daerah terpeencil sekalipun (Utari dan Putu, 2014) ${ }^{10}$. Beik (2010) ${ }^{11}$ menjelaskan dalam struktur perekonomian nasional, proporsi kelompok usaha mikro, yang mencerminkan kaum marjinal atau kaum pra-sejahtera tersebut, justru menempati urutan teratas. Meski proporsi usaha mikro mendominasi struktur perekonomian nasional, kesempatan atau akses mereka terhadap sumber pembiayaan atau permodalan yang berasal dari institusi perbankan dan keuangan formal masih sangat terbatas. Mereka dianggap sebagai kelompok yang tidak bankable, sehingga dianggap tidak layak menerima kucuran kredit. Karena itu, dengan kondisi seperti ini, mendorong perkembangan lembaga keuangan mikro Islam (LKMI) telah menjadi kebutuhan yang sangat mendesak, sebagai upaya untuk memperbesar akses finansial bagi kelompok masyarakat marjinal tersebut. Apalagi secara konsep, ekonomi syariah memiliki keberpihakan yang sangat nyata terhadap pengembangan usaha mikro yang dimiliki oleh masyarakat. Lembaga keuangan mikro syariah yang dimaksudkan yaitu BMT. BMT memiliki peran yang sangat aktif terhadap pengembangan usaha mikro. Melalui BMT, masyarakat miskin dan pedagang kecil (pengusaha usaha mikro) akan dilepaskan dari jeratan sistem riba (bunga) dan mengalihkannya kepada sistem ekonomi Islam yang disebut dengan bagi hasil. BMT mendapat respon yang positif dari masyarakat, karena BMT tergolong lebih lincah dan fleksibel, karena tak fully regulated. Hal ini meyebabkan konsep BMT mampu di hadirkan di area masyarakat kecil.

\section{Faktor-Faktor yang mempengaruhi Kesuksesan Usaha Mikro melalui Pembiayaan Mudharabah pada BMT}

\section{a. Pembinaan}

Pembinaan yang dilakukan merupakan wujud pemberdayaan sebagai dorongan bagi masyarakat untuk mengasah kemampuanyang mereka miliki serta dapat dijadikan bekal ilmu pengetahuan dan keterampilan bagi masyarakat yang ingin membuka usaha mikro (Feni dkk, 2013) ${ }^{12}$.Para calon atau pengusaha usaha mikro untuk mengetahui pengembangan usahanya dapat melakukan konsultasi dengan BMT mengenai rencana atau pengembangan usaha yang dijalankannya. BMT akan melakukan pembinaan bagi

10 Tri Utari, P. M. D. Pengaruh Modal, Tingkat Pendidikan dan Teknologi Terhadap Pendapatan Usaha Mikro Kecil dan Menengah (UMKM) di Kawasan Imam Bonjol Barat Denpasar. E-Jurnal Ekonomi Pembangunan Universitas Udayana, Vol.3(12), 576-585, 2014.

11 Beik, I. S. Menguji Efektivitas Pembiayaan Mudharabah BMT Bagi UMKM. Republika, 23. Retrieved from http://fem.ipb.ac.id/d/iqtishodia/2014/Iqtishodia_20140925.pdf, 2014.

12 Feni Dwi Anggraini, Imam Hardjanto, A. H. Pengembangan Usaha Mikro, Kecil, dan Menengah (UMKM) melaluiFasilitasi Pihak Eksternal dan Potensi Internal (Studi Kasus pada Kelompok Usaha "Emping Jagung" di Kelurahan Pandanwangi Kecamatan Blimbing, Kota Malang). Jurnal Administrasi Publik (JAP), Vol.1(6), 1286-1295, 2013. 
usaha untuk mewujudkan kinerja usaha mikro yang lebih baik. BMT akan membuka diri agar segala hambatan dan kendala usaha mikro mampu ditanggulangi secara tuntas.

Pembinaan perlu dilakukan karena dalam usaha mikro terdapat kendala keterbatasan SDM dalam masyarakat menengah kebawah (pelaku usaha mikro) yaitu dari segi pendidikan formal maupun pengetahuan dan keterampilannya sangat berpengaruh terhadap manajemen pengelolaan usahanya, sehingga kadang usaha mikro sulit untuk berkembang dengan optimal. Disamping itu, minimnya pengetahuan mengenai teknologi akan menyulitkan mereka dalam meningkatkan daya saing produk yang dihasilkan. Oleh karena itu betapa pentingnya pembinaan yang berguna untuk memberikan bekal ilmu pengetahuan dan keterampilan dalam mengembangkan usaha yang dijalankannya.

Menurut Karsidi (2007) ${ }^{13}$ perlunya pendampingan (pembinaan) menyadari perannya sebagai fasilitator dan bukannya sebagai pelaku atau guru. Untuk itu diperlukan sikap rendah hati serta kesediaan belajar dari masyarakat (pelaku usaha mikro) dan menempatkan pelaku usaha mikro sebagai narasumber utama dalam memahami keadaan masyarakat itu sendiri. Bahkan dalam penerapannyamasyarakat (pelaku usaha mikro) dibiarkan mendominasi kegiatan, dalam hal ini yaitu usaha mikro. Walau kadang peran pembina lebih besar, harus diusahakan agar secara bertahap peran itu bisa berkurang sehingga memperlihatkan peran pelaku usaha mikrolah yang aktif.

Pembinaan dilakukan dengan memberikan pelatihan untuk bimbingan kepada pelaku usaha mikro yang dilakukan oleh BMT guna meningkatkann kualitas produksi terhadapa usaha yang dilakukan sehingga mampu mengembangkan kinerja usaha. Pembinaan juga dilakukan dengan memberikan pelatihan untuk pengembangan usaha (produksi, pembukuan, dan pemasaran) sehingga diharapkan pada setiap pelaku usaha mikro dapat melakukan produksi dengan lebih baik, melakukan pembukuan agar setiap catatan keuangan tertata secara rapi dan rinci, serta melakukan pemasaran yang "out of the box".

b. Pengawasan

Pada dasarnya pengawasan bank syariah dimaksudkan untuk meningkatkan keyakinan dari setiap orang yang mempunyai kepentingan dengan bank, bahwa bankbank dari segi finansial tergolong sehat, dan sesuai dengan ajaran Islam (DSN MUI) serta di dalam bank tidak terkandung segi-segi yang merupakan ancaman terhadap kepentingan masyarakat yang menyimpan dananya di bank (Syukron, 2012) ${ }^{14}$. Hal ini tidak jauh berbeda dengan BMT sebagai lembaga keuangan mikro Islam. Kesesuain kegiatan transaksi antara shahibul maal dengan mudharib harus diawasi oleh pihak ketiga agar tidak terjadi perbedaan pendapat antar keduabelah pihak. Dalam hal ini yang dimaksud pihak ketiga adalah Dewan Pengawas Syariah (DPS).

DPS harus ada secara khusus disetiap BMT gunamengetahui serta menilai kinerja BMT dalam menjalankan kegiatannyasesuai dengan prinsip syariah atau belum. Hal ini perlu dilakukan untuk meminimalisir ketidaksesuaian pihak mudharib dengan shahibul maal dalam menjalankan kesepakatan yang telah dibuat. Pengawasan dilakukan agar modal yang diberi oleh BMT melalui pembiayaan mudharabah untuk usaha mikro sesuai dengan DSN MUI baik kerugian ataupun keuntungan yang didapat kedua belah pihak dengan tujuan meningkatkan kinerja usaha mikro. Usaha mikro akan berjalan dengan baik dan terus meningkat apabila dilakukan tanpa ada kendala ataupun hambatan yang disebakan oleh akad antara shahibul maal dan mudharib.

13 Karsidi, R. Pemberdayaan Masyarakat untuk Usaha Kecil dan Mikro. Jurnal Penyuluhan IPB, Vol.3(2), 136145, 2007.

14 Syukron, A. Pengaturan dan Pengawasan pada Bank Syariah. Jurnal Ekonomi Dan Hukum Islam, Vol.2(1), 22-41, 2012. 


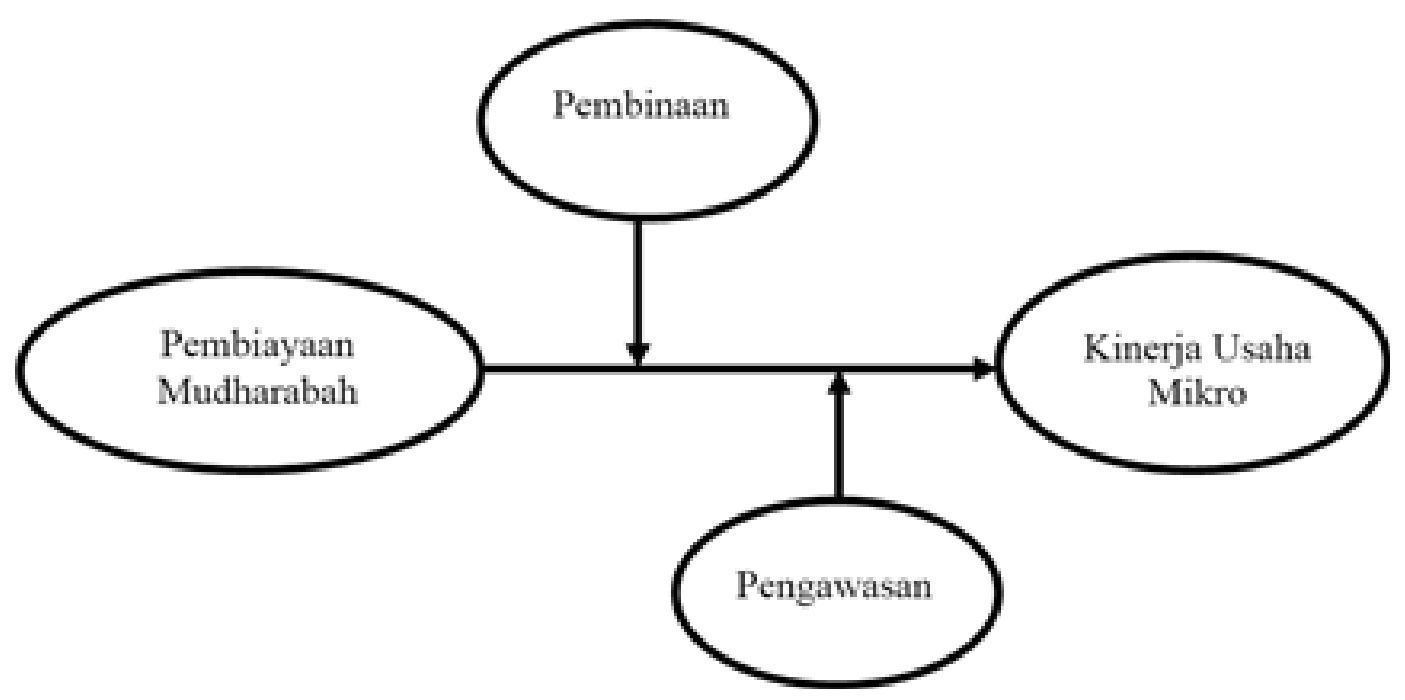

\section{Pembiayaan Mudharabah}

Pembiayaan mudharabah merupakan pembiayaan bagi hasil. Pembiayaan bagi hasil pada sebagian lembaga keuangan masih rendah. Hal ini dikarenakan pembiayaan bagi hasil masuk dalam kategorihigh risk, karena keuntungan maupun kerugian akan ditanggung oleh kedua belah pihak (Dewi, 2016) ${ }^{15}$. Meski demikian pembiayaan bagi hasil menerapkan prinsip keadilan bagi kedua belah pihak.

Bentuk-bentuk pembiayaan untuk usaha mikro dengan menggunakan sistem bagi hasil. Adapun kegiatan lembaga keuangan mikro Islam dalam hal pembiayaan Islam meliputi jual beli, simpanan wadiah, mudharabah, musyarakah, zakat, dan jasa lainnya (Hertanto Widodo, dkk, 1999) ${ }^{16}$.

Menurut Ridwan dan Donny (2015) $)^{17}$ menjelaskan bahwa pembiayaan mudharabah merupakan pembiayaan yang dipromosikan dalam Al-Quran dan Al-Hadist. Fatwa DSN MUI $(2000)^{18}$ menimbang pembiayaan mudharabah yaitu akad kerjasama suatu usaha antara dua pihak di mana pihak pertama (malik,shahib al-mal, lembaga keuangan Islam) menyediakan seluruh modal, sedang pihak kedua ('amil, mudharib, nasabah) bertindak selaku pengelola, dan keuntungan usaha dibagi di antara mereka sesuai yang dituangkan dalam kontrak. Hal itu dilandaskan dari :

a. Firman Allah QS. Al-Nisa (4):29:

"Hai orang yang beriman! Janganlah kalian saling memakan (mengambil) harta sesamamu dengan jalan batil, kecuali dengan jalan perniagaan yang berlaku dengan sukarela antaramu..."

b. Firman Allah QS. al-Maidah (4):1:

"Hai orang-orang yang beriman! Penuhilah akad-akad itu..."

c. Firman Allah QS. Al-Baqarah (2):283:

“...Maka,jika sebagian kamu mempercayai sebagian yang lain, hendaklah yang dipercayai itu menunaikan amantanya dan hendaklah ia bertakwa kepada Allah Tuhannya...”

d. Hadis Nabi riwayat Thabrani:

" Abbas bin Abdul Muthalib jika menyerahkan harta sebagai mudharabah, ia

15 Dewi, A. P. Pembiayaan Bagi Hasil Sektor Usaha Mikro di BMT Hasanah Ponorogo. Muslim Heritage, Vol.1(1), 73-85, 2016.

16 Widodo, H. Panduan Praktis Operasional Baitul Mal Wa Tamwil (BMT). Bandung: Mizan, 1999.

17 Agus Ridwan, D. A. L. P. The Rotating Multiple Wheels Management Model for Mitigating The Risks of Mudharabah Financing to Small Firms. In Conference on Business Management Research II (CBMR II 2015) School of Business Management, Universiti Utara Malaysia, 06010 Sintok, Kedah, Malaysia (pp. 18-24), 2015.

18 FATWA DSN MUI Pembiayaan Mudharabah, 2000. 
mensyaratkan kepada mudharib-nya agar tidak mengarungi lautan dan tidak menuruni lembah, serta tidak membeli hewan ternak. Jika persyaratan itu dilanggar, ia (mudharib) harus menanggung risikonya. Ketika persyaratan yang ditetapkan Abbas itu didengar Rasulullah, beliau membenarkannya." (HR.Thabrani dari Ibnu Abbas).

e. Hadis Nabi riwayat Ibnu Majah dari Shuhaib:

"Nabi bersabda, 'Ada tiga hal yang mengandung berkah: jual beli tidak secara tunai, muqaradhah (mudharabah), dan mencampur gandum dengan jewawut untuk keperluan rumah tangga, bukan untuk dijual." (HR. Ibnu Majah dari Shuhaib).

Mudharabah mirip dengan konsep kemitraan di mana modal keuangandisediakan oleh satu atau lebih (shahibul maal) dan pekerjaan dilakukan oleh mudharib. Dana yang digunakan dalam beberapa aktivitas dan kegiatan untuk jangka waktu yang tetap. Pemodal dan manajer proyek berbagi keuntungan dalam yang telah disetujui berdasarkan akad (Ahmed, 2014) ${ }^{19}$.

Menurut Kartiko A. Wibowo (2016) ${ }^{20}$ Mudharabah adalah suatu perjanjian usaha antara pemilik modal menyediakan seluruh dana yang diperlukan dan pihak pengusaha melakukan pengelolaan atas usaha. Hasil usaha bersama ini dibagi sesuai dengan kesepakatan ketika akad pembiayaan dituangkan dalam bentuk nisbah bagi hasil misalnya 70:30 atau 60:40.

Mudharabah adalah jenis khusus kemitraan di mana salah satu pasangan memberikan uang kepada orang lain untuk berinvestasi di perusahaan komersial. investmen berasal dari mitra pertama yang disebut rabbulmal, sedangkan manajemen dan pekerjaan adalah bertanggungjawab eksklusif lainnya, yang disebut mudharib.

\section{Skema Pembiayaan Mudharabah}

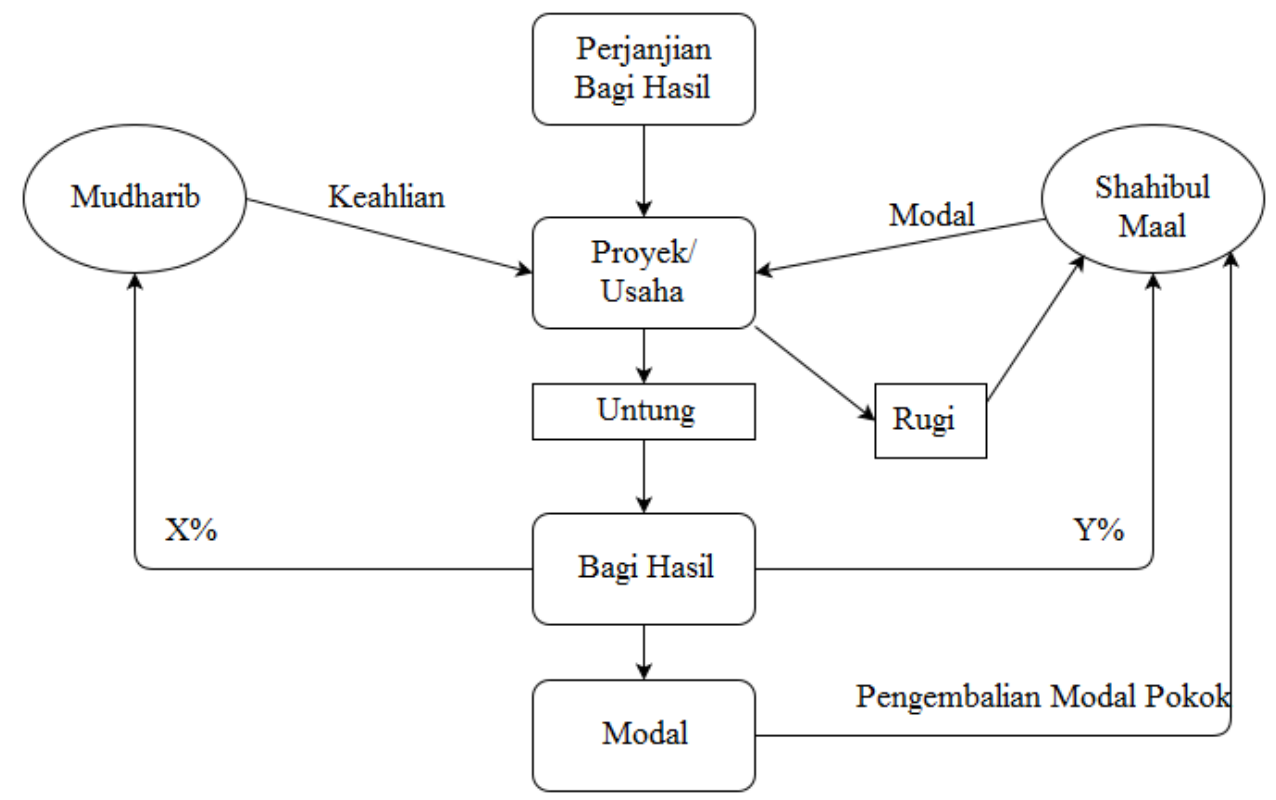

Sumber : Antonio, $2001^{21}$

Skema pembiayaan mudharabah di atas menjelaskan bahwa pembiayaan mudharabah merupakan pembiayaan bagi hasil dimana pihak shahibul maal (BMT) memberi seluruh modal sebesar 100\% yang diberikan kepada mudharib (nasabah) yang mempunyai keahlian untuk mengelola suatu proyek atau usaha. Dalam pelakasanaannya kedua belah pihak melakukan

19 Ahmed, H. Islamic Banking and Shari'ah Compliance: A Product Development Perspective. Journal of Islamic Finance, Vol.3(2), 015-029, 2014.

20 Widiyanto bin Mislan Cokrohadisumarto, Abdul Ghafar Ismail, K. A. W. BMT Praktik dan Kasus (1st ed.). Jakarta: PT RajaGrafindo Persada, 2016.

21 Antonio, M. S. Bank Syariah dan Teori ke Praktek. Jakarta: Gema Insani Press Indonesia, 2001. 
perjanjian atau akad berdasarkan kesepakatan bersama termasuk pembagian nisbah bagi hasil. Di dalam pembiayaan mudharabah, apabila proyek atau usaha yang dijalankan mengalami keuntungan maka kedua belah pihak mendapatkan bagi hasi, namun jika terjadi kerugian maka yang menanggung adalah shahibul maal dengan catatan bahwa keerugian yang terjadi bukan merupakan kesalahan atau penyimpangan yang dilakukan oleh mudharib.

\section{Pelaksanaan atau Operasional Pembiayaan Mudharabah}

Menurut penjelasan Fatwa DSN MUI No.07/DSN-MUI/IV/2000 bahwa standar kesyariahan pembiayaan mudharabah dapat disimpulkan menjadi :

1. Usaha atau proyek yang dijalankan antara shahibul maal dan mudharib adalah suatu usaha yang produktif. Produktif artinyamampu memberi hasil atau manfaat dalam jumlah besar bagi semua unsur yang terlibat dalam suatu usaha. Serta usaha yang dijalankan tidak melanggar ketentuan ajaran Islam.

2. Usaha yang dijalankan merupakan hasil keputusan dan telah disepakati bersama antara shahibul maal dan mudharib.

3. Segala bentuk perjanjian dan kesepakatan tertuang dalam bentuk tersirat dan tersurat sehingga ada bukti yang konkrit.

4. Sahibul maal sebagai penyedian dana harus menyerahkan dana kepada mudharib secara tunai baik bertahapa atau tidak dan bukan dalam bentu piutang.

5. Apabila proyek atau usaha yang dijalankan shahibul maal dan mudharib mengalami kerugian atau kebangkrutan dikarenakan kecuali penyimpangan yang dilakukan mudharib ditanggung oleh shahibul maal.

6. Nisbah bagi hasil berdasarkan profit sharing atau revenue sharing sesuai kesepakatan antara shahibul maal dan mudharib.

7. Pembiayaan tidak menggunakan jaminan karena berlandaskan kepercayaan. Tetapi agar dapat meminimalisir penyimpangan yang dilakukan mudharib makan shaihibul maal dapat meminta jaminan. Jaminan hanya dapat dicairkan apabilan mudharib terbukti melakukan penyimpangan.

8. Apabila terjadi perselisihan antara shahibul maal dan mudharib, maka penyelesaian dilakukan melalui Badan Arbitrasi Syariah serelah tidak tercapai kesepakatan melalui musyawarah.

\section{Mudharabah Pembiayaan Ideal untuk Usaha Mikro}

Khan (2008) 22 mengungkapkan enam prinsip keuangan Islam : larangan riba(bunga), dan pelaksanaan murabahah, mudharabah, musyarakah, ijarah, dan pembiayaan qard alhasan. Bunga dianggap instrument yang tidak adil karena pada dasarnya pada bunga terdapat penindasan melalui eksploitasi dan bunga mentransfer kekayaan dari orang miskin ke orang kaya. Oleh karenanya larangan riba dilakukan untuk menegakan prinsip keadilan dalam Islam antara pemberi dana dan pengusaha. Usmani $(2002)^{23}$ menjelaskan bahwa pembiayaan murabahah merupakan tahap awal untuk menghindari bunga dan merupakan pembiayaan yang ideal dalam keuangan Islam dan penggunaannya dibatasi hanya untuk kasus-kasus dimana pembiayaan mudharabah dan musyarakah belum dapat dilaksanakan dengan baik. Ini menunjukan bahwa pembiayaan mudharabah dan musyarakah adalah konsep pembiayaan yang ideal.

Adnan dan Didi (2013) $)^{24}$ menjelaskan bahwa pembiayaan mudharabah dikatakan ideal karena memiiki peran dalam perkembangan pemberdayaan ekonomi Islam yang sangat vital.

22 Khan, A. A. Islamic Microfinance Theory, Policy and Practice. Brimingham: Islamic Relief Worlwide, 2008.

23 Usmani, M. M. T. An Introduction to Islamic Finance (1st ed.). Karachi: Maktaba Ma'ariful Qur'an, 2002.

24 Adnan, M. A., \& Didi Purwoko. Analisis Faktor-Faktor yang Mempengaruhi Rendahnya Pembiayaan Mudharabah Menurut Perspektif Manajemen Bank Syariah dengan Pendekatan Kritis. Jurnal Akuntansi Dan Investasi, Vol.14 (1), 14-31, 2013. 
Pembiayaan mudharabah mampu menciptakan kondisi yang adil, seimbang dan menekankan pada prestasi baik berupa kerja maupun risiko yang ditanggung. Namun dampak risiko yang tinggi inilah yang menyebabkan mudharabah masih sangatlah jarang dilakukan perbankan syariah ataupun lembaga keuangan mikro Islam lainnya yang selalu mengedepankan produk murabahah(jual beli). Unggulnya produk dengan skema jual beli (murabahah) dikarenakan keuntungan yang jelas dalam produk tersebut, sementara risiko yang mungkin terjadi juga sangat kecil, berbeda dengan pembiayaan mudharabah yang memiliki risiko yang tinggi dikarenakandari pihak bank menyerahkan modal kerja tidak dengan disertakan jaminan. Maka dari itu dari pihak shahibul maal harus benar-benar teliti dalam hal memilihmudharib yang akandiberi modal kerja.

Namun demikian, pembiayaan mudharabah merupakan pembiayaan yang ideal karena dimana pihak shahibul maal dan mudharib merasa adil oleh suatu hasil yang diperoleh dalam menjalakan proyek atau usaha yang dilakukan atas dasar kesepakatan bersama.

\section{PENUTUP}

Pembiayaan mudharabahmerupakan pembiayaan yang ideal serta merupakan pembiayaan primer di dalam pembiayaan Islam. Skema pembiayaan mudharabah telah diterapkan pada sebagian BMT di Indonesia. Tidak semua BMT menyediakan pembiayaan mudharabah karena masih banyaknya kekhawatiran terhadap pembiayaan mudharabah yang berisiko tinggi. Oleh karena itu, penerapan salah satu prinsip syariah yaitu pembiayaan mudharabah masih tergolong sangat rendah pada BMT di Indonesia.

Dengan adanya pembinaan dan pengawasan terhadap pembiayaan mudharabah pada BMT mampu meminamlisir kegagalan kinerja usaha mikro. Hal ini dikarenakan dengan adanya pembinaan dan pengawasan kinerja usaha mikro dapat berjalan bersamaan dengan baik. Keberhasilan BMT sebagai lembaga keuangan mikro Islam dalam menerapkan prinsip pembiayaan syariah dapat dijadikan contoh bagi lembaga keuangan Islam lainnya.

\section{DAFTAR PUSTAKA}

Adnan, M. A., \& Didi Purwoko. (2013). Analisis Faktor-Faktor yang Mempengaruhi Rendahnya Pembiayaan Mudharabah Menurut Perspektif Manajemen Bank Syariah dengan Pendekatan Kritis. Jurnal Akuntansi Dan Investasi, Vol.14 (1), 14-31.

Agus Ridwan, D. A. L. P. (2015). The Rotating Multiple Wheels Management Model for Mitigating The Risks of Mudharabah Financing to Small Firms. In Conference on Business Management Research II (CBMR II 2015) School of Business Management, Universiti Utara Malaysia, 06010 Sintok, Kedah, Malaysia (pp. 18-24).

Ahmed, H. (2014). Islamic Banking and Shari'ah Compliance: A Product Development Perspective. Journal of Islamic Finance, Vol.3(2), 015-029.

Antonio, M. S. (2001). Bank Syariah dan Teori ke Praktek. Jakarta: Gema Insani Press Indonesia

Badan Pusat Statitistik: Industri Mikro dan Kecil. (2016). Retrieved from https://www.bps.go.id/ Subjek/view/id/170\#subjekViewTab3|accordion-daftar-subjek2

Bagaskara, I. G. K. (2013). Lembaga Keuangan Mikro di Indonesia. Jurnal Buletin Studi Ekonomi, Vol.18(2), 114-125

Bank Indonesia: Statistik Perbankan Syariah. (2016). Retrieved from http://www.bi.go.id/id/ statistik/perbankan/syariah/Default.aspx

Beik, I. S. (2014). Menguji Efektivitas Pembiayaan Mudharabah BMT Bagi UMKM. Republika, 23. Retrieved from http://fem.ipb.ac.id/d/iqtishodia/2014/Iqtishodia 20140925.pdf 
Dewi, A. P. (2016). Pembiayaan Bagi Hasil Sektor Usaha Mikro di BMT Hasanah Ponorogo. Muslim Heritage, Vol.1(1), 73-85

FATWA DSN MUI Pembiayaan Mudharabah (2000)

Feni Dwi Anggraini, Imam Hardjanto, A. H. (2013). Pengembangan Usaha Mikro, Kecil, dan Menengah (UMKM) melalui Fasilitasi Pihak Eksternal dan Potensi Internal (Studi Kasus pada Kelompok Usaha "Emping Jagung" di Kelurahan Pandanwangi Kecamatan Blimbing, Kota Malang). Jurnal Administrasi Publik (JAP), Vol.1(6), 1286-1295

Indriyatni, L. (2013). Analisis Faktor-Faktor yang Berpengaruh Terhadap Keberhasilan Usaha Mikro dan Kecil ( Studi pada Usaha Kecil di Semarang Barat ). Jurnal STIE Semarang, Vol.5(1), 54-70

Karsidi, R. (2007). Pemberdayaan Masyarakat untuk Usaha Kecil dan Mikro. Jurnal Penyuluhan IPB, Vol.3(2), 136-145

Khan, A. A. (2008). Islamic Microfinance Theory, Policy and Practice. Brimingham: Islamic Relief Worlwide

Republika. (2015). Aset BMT Indonesia Capai Rp 4,7 Triliun. Retrieved from http://www. republika.co.id/berita/ekonomi/syariah-ekonomi/15/03/22/nlmhlb-aset-bmt-indonesia-capairp-47-triliun.

Semuel, H. (2014). Penerapan Kebijakan Penggunaan Energi Listrik Terhadap Kinerja Usaha Mikro Kecil dan Menengah di Provinsi Jawa Timur. Jurnal Manajemen Pemasaran, Vol.8(1), $3-46$

Syukron, A. (2012). Pengaturan dan Pengawasan pada Bank Syariah. Jurnal Ekonomi Dan Hukum Islam, Vol.2(1), 22-41

Tri Utari, P. M. D. (2014). Pengaruh Modal, Tingkat Pendidikan dan Teknologi Terhadap Pendapatan Usaha Mikro Kecil dan Menengah (UMKM) di Kawasan Imam Bonjol Barat Denpasar. E-Jurnal Ekonomi Pembangunan Universitas Udayana, Vol.3(12), 576-585

Usmani, M. M. T. (2002). An Introduction to Islamic Finance (1st ed.). Karachi: Maktaba Ma'ariful Qur'an

Widiyanto. (2007). Effectiveness and Sustainability of Baitul Mal Wat Tamwil Financing In The Development of Micro-enterprises In Central Java, Indonesia. Phd Thesis, UPM Malaysia

Widiyanto bin Mislan Cokrohadisumarto, Abdul Ghafar Ismail, K. A. W. (2016). BMT Praktik dan Kasus (1st ed.). Jakarta: PT RajaGrafindo Persada

Widodo, H. (1999). Panduan Praktis Operasional Baitul Mal Wa Tamwil (BMT). Bandung: Mizan 